\title{
Productivity effects of human capital: an empirical investigation of health and higher education in South Africa*
}

\author{
Josue Mbonigaba ${ }^{1}$, Akinola Gbenga Wilfred $^{2}$
}

\begin{abstract}
The huge burden of diseases, poor higher educational outcomes in South Africa and their interaction on affecting productivity of human capital requires investigation for a context-specific policy advice. To this effect, the purpose of this paper is to investigate this relationship, alongside other factors, viewing human capital from the perspective of health, higher education enrolment (HEE) and higher education graduates (HEG). The study adopts time series autoregressive distributive lag (ARDL) with data covering the period 1980 - 2015. The study has found that, while GDP grows, employment rates and HEE have a positive impact on productivity in South Africa; capital stock and life expectancy exhibited an inverse relationship with productivity. These findings support the hypothesis that widespread antiretroviral therapy and resulting survival, without corresponding school sector focus on needed skills, relate negatively to productivity. The findings further support that enrolments affect positively productivity because they comprise individuals who are partly skilled in programs needed by the economy. Finally, they support the hypothesis that graduate outputs relate negatively to productivity because of mismatch of graduation skills and the economy's need. As a policy suggestion, combined effort at school and health sector is needed in South Africa for increased productivity.
\end{abstract}

Key words: productivity, human capital, higher education enrolment, higher education graduates, ARDL, South Africa

JEL classification: I1, I15, I21, I23, J24, O4

\footnotetext{
Received: 19-06-2018; accepted: 28-02-2019

1 Associate Professor, School of Accounting, Economics and Accounting, College of Law and Management, University of Kwazulu Natal, South Africa. Scientific affiliation: health economics.E-mail: Mbonigaba@ukzn.ac.za. Phone: +27768706031 (corresponding author).

2 PhD, School of Accounting, Economics and Finance, College of Law and Management Studies, University of KwaZulu-Natal, Westville, Durban, 4000, South Africa. Scientific affiliation: human capital development. Phone:+27739210781. E-mail: gbenga.akinola@fuoye.edu.ng.
} 


\section{Introduction}

Higher education outcomes and health status are expected to enhance each other to increase human capital productivity. They are also likely to increase the productivity of other factors of production through innovation and technological advancement. However, in countries with a high burden of diseases and unfavorable higher educational outcomes, the effects of higher education and health, as components of human capital, on productivity might exhibit peculiar evidence with implied policy responses. Therefore, the purpose of this study is to investigate productivity effect of human capital in South Africa, a country where educational outcomes and health outcomes have remained low for a long period (Branson and Leibbrandt, 2013, Zuma et al., 2014).

South Africa has suffered a great burden of chronic diseases, particularly the burden of HIV/AIDS for many years. Since the advent of HIV epidemic to date, the annual rates of new HIV infections have been the highest in the world, with about at least 100,000 people being infected annually. In 2017, it was estimated that about 270,000 new infections occurred in South Africa (AVERT 2017). Furthermore, HIV has remained the top cause of death in the country with studies estimating that about 330,000 lives have been lost to HIV/AIDS between the year 2000 and 2005 for example (Chigwedere et al., 2008; Zuma et al., 2014). With its health weakening effects, HIV has been believed to be the cause of the highest burden of TB observed in the county. Indeed, the TB epidemic in the country has been the worst in the world (Mayosi and Benatar, 2014). TB incidence progressively increased from 300 per 100,000 individuals in the early 1990 s to 600 per 100,000 in the early 2000 s and to 950 per 100,000 people in 2012 (Rensburg et al., 2005; Katz et al., 2013). Furthermore, in 2017, the country was home to $0.7 \%$ of the global population but suffered disproportionately from the world burden of diseases such as, depression, tuberculosis and HIV/AIDS (Stander et al., 2016).

These health outcomes have largely come from limited and ineffective preventive interventions (Chigwedere et al., 2008; Zuma et al., 2014) and in huge inequalities in socioeconomic status which have made the majority of the poor population to indulge in risky health behaviors (Wabiri and Tafta, 2013). The country has also been characterized by limited access to health care services for the overwhelming majority of the population. Limited access arose from a situation in which $20 \%$ of the countries health resources serve the poor $(80 \%)$ segment of the population while $80 \%$ of the resources serve the richer segment $(20 \%)$ of the population (Zuma et al., 2014). This situation has in turn resulted in adverse health outcomes in the general population.

It is only in the late 2000s that the government started taking the HIV and TB epidemic seriously by embarking on prevention campaigns (Kevany et al., 2013) and by launching one of the biggest country-level antiretroviral programs in the 
world. As a result of this response, life expectancy increased from 56.5 years in 2009 to 58.5 years in 2014 (Zuma et al., 2014). Furthermore, the rollout of the national health insurance (NHI) project aiming to provide an appropriate health package to every citizen started in 2010 but has been moving slowly due to lack of funds (Omarjee, 2018). Once fully implemented, NHI is expected to enable access to health care for most members of the previously marginalized communities.

In spite of these efforts, the burden of diseases persists in the country. In 2017, about 7.2 million (12.6\% of the population) were HIV positive (Statistics South Africa, 2017) and were on government funded antiretroviral treatments. Furthermore, people that are dying from TB and HIV epidemic continue to be significant in numbers. This situation suggests that the burden of diseases is far from being over. The direct implication of the burden of the diseases on productivity happens through deaths and loss of productive time due to absenteeism as well as through other general unobservable effects on foreign and domestic investment, tourism, the internal mobility of labour and land use (Mayosi and Benatar, 2014; Cole and Neumayer, 2006).

Besides the burden of diseases, the legacy of apartheid has made South African higher education system to be characterised by extreme inequalities in terms of schooling, race, class, and financial resources (HESA, 2018). Widening higher education access to previously marginalised groups by doubling enrolment from these groups from 1994 to 2015 did not resolve the problem (HESA, 2018). In particular, lower education quality at school level (Van der Berg, 2008) continued to lead to non-completion of university degrees. Other issues concern program choices with most of these HEE not targeting science, mathematics and technology (Fleisch, 2008) programmes which the economy needs most (Worldlink Africa, 2013). The third issue has been the high dropout in the country's higher education system with students from poorly resourced schools being the most affected. All these issues have contributed negatively to human capital productivity in different fashions (OECD, 2018, Branson and Leibbrandt, 2013).

Against this background, it follows that health and education are likely to interact to influence productivity of each other and the productivity of other factors of production. We therefore hypothesize that widespread antiretroviral without corresponding school sector focus on the economy's needed skills, will result in reduced effects of survival on productivity. It is furthermore hypothesized that enrolments will have a positive effect on productivity because enrolments include students who enrol in the economy's needed programmes. These students subsequently drop out but become productive because they join the economy with some relevant and productive skills. Finally, we hypothesize that graduate outputs will relate negatively to output because those who graduate have largely skills that mismatch the economy's skills requirement. These hypotheses are tested by incorporating HEE, HEG and health (HL) in an equation and by estimating 
their controlled effects on productivity. We use the autoregressive distributive lag (ARDL), the Cob-Douglass production function and data covering 1980-2015 to this effect.

The remainder of this paper is organized as follows. Section 2 reviews the theoretical and empirical literature on the subject and section 3 discusses the methodology and the Cobb Douglas production function adopted to build the study's model. Section 4 presents the results and section 5 discuss the results. Section 6 concludes the paper.

\section{Literature review}

\subsection{Theoretical literature}

Human capital can be defined as a set of skills, work experience, health and other intangible characteristics such as motivation and work ethics (Forbes et al , 2010: xiii) that contribute to production. As the definition entails, education through which people acquire skills and health are essential components of human capital. It follows that the productivity effects of human capital from the perspective of health and higher education can be explained by the theories of Becker (1962) and Grossman (1972).

According to human capital theory (Becker, 1962), people become more productive due to their increase in knowledge and skills. This increase in productive capacity happens through better planning, organization and efficiency in operating procedures (Lindahl \& Krueger (2001). Higher education enrolments and graduates being the components of education that are expected to yield high level skills; they present good educational artefacts that can be investigated based on this theory. A related theory, focusing on health as a form of human capital is the Grossman (1972) theory. In the latter, health is a durable capital stock that enhances the productivity of healthy times. According to the theory, healthy workers, relative to unhealthy ones, are more productive and less likely to be absent from work (Lindahl \& Krueger, 2001).

Health and higher education might however not contribute to human capital productivity in isolation but through mutual reinforcement. The latter can be argued in many ways. First, healthy times by Grossman (1972) become more productive when a person has more education (skills) (Forbes et al., 2010). In other words, the more the people are healthy, the more they are available for labour supply (Suhrcke et al., 2005), and the more their skills are put to productive use. Second, a person with the expectation of living longer is likely to invest in education. Third, education enhances healthy workers efficiency by better organisation, planning and usage of healthy days. Fourth, workers with a high level of education are mentally 
and physically more robust and energetic that healthier workers without education (Suhrcke et al., 2005).

As components of human capital, health and education not only reinforce the productivity of human capital but also increase the productivity of other factors of production. The influence on other factors of production happens through innovations and technical changes (Mankiw et al., 1992). Skills and knowledge's effect on productivity of other factors of production is premised on the hypothesis that this knowledge plays a critical role in adopting new technology, in creating positive production externalities and in better utilization of other factors (De la Fuente, 2011; Becker, 1962; Nelson and Phelps, 1966; Lucas 1988). The widespread effects of education and health on other factors of production operate through increased savings, investments, reduction in fertility and many unobservable productivity benefits referred to as total factor productivity (Bloom and Canning, 2002).

In light of the South African context, these theoretical artefacts imply that productivity effects of higher education and health cannot be determined a priori and needs to be estimated. Before such estimates are produced, previous empirical literature is reviewed first.

\subsection{Empirical literature}

There have been recently a number of studies investigating the prediction of human capital theory. Most of these studies found significant effects of education on productivity (Forbes et al., 2010, De la Fuente, 2011). In a survey of the empirical literature, De la Fuente (2011) found that on balance, investment in education had a positive, significant and sizable effect on productivity growth. The study found further that unexpected results on the linkage were largely due to difficulties in measuring human capital because of its multi-dimensional components. Many of the studies have been micro-econometric in nature, investigating the relationship between education and productivity at the firm and household levels (Forbes, 2010; Nwosu, 2015). Some other studies, using national or cross-country data found that education had significant returns in terms of its impact on productivity ( $\mathrm{Li}$ and Huang, 2009; Eggoh et al., 2015, among many other studies).

Studies analyzing the role of health on productivity have also been both at a microeconomic and macroeconomic level. In South Africa, evaluating the relationship between health and labor market and using household data, Nwosu (2015) found that health had significant effect on labour force participation of between $20 \%$ and $33 \%$ in shorter term, depending on the measure. In a longer term, a significant association of up to $16 \%$ for males and $11 \%$ for females was found. At a macro level, Gyimah-Brempong and Wilson (2004) evaluated the role of health on the growth rate of per capita income in Sub-Saharan Africa. They found that the 
latter was strongly and positively affected by the growth of health human capital. They showed in particular that about $22 \%$ of per capita growth could be explained by health. They found however, that in countries with large endowments of health, health effects on productivity were diminished.

Other empirical work on the interaction of health and education in enhancing human capital productivity emphasized on controlling the effect of health on education when estimating productivity of these two elements of human capital. In a study evaluating the future potential benefits of increased levels of education and reduced levels of chronic illness to support proposed educational and health reform agenda in Australia, Forbes et al (2010) found that these reforms were to increase labour participation and productivity. Another study by Li and Huang $(2009,2010)$ investigated the sources of productivity and economic growth in a group of Asian countries including China. Distinguishing pre-Asian crisis period (1997) from post Asian crisis. The study found that the roles of health and education on productivity both for the whole sample and sub-samples periods were positive and significant. The study found however, a more stable impact of health on productivity and suggested a more health-related policy focus. Similar findings were reported in McDonald and Roberts (2002). Evaluating the effect of health and education on growth in African countries, Eggoh et al. (2015) found that spending on health and education albeit complimentary in enhancing productivity; they had a negative impact on productivity. The study found further that human capital stock indicators have a slight positive effect. Policy suggestion from the study was that public investment in education and health as well as their efficiency should be jointly increased in order to expect positive impact on productivity. In a related study, Ram (2007) adopted the intellectual factor of intelligence Quotient (IQ) as another important aspect of human capital to evaluate the effects of health and education on productivity. The results indicated that the impact of IQ on per capita income growth is more important than the effect of health. Ram (2007) also submitted that the impact of IQ is always greater than education and life expectancy effects. Colantonio et al. (2010) evaluated the relationship between health, education and economic development indicators from 2003 to 2007. Using multidimensional scaling effects, they found that countries that prioritized health and education witnessed higher productivity growth than those with lower health and education levels. Other studies evaluating the effect of human capital suggested an interaction between accumulation of knowledge and physical capital in enhancing productivity (De La Fuente, 2011). In the higher education realm, studies have reported on how health influence education and how education and health influence productivity of other factors of production (Cole and Neumayer, 2006).

These studies used a variety of modelling, where productivity was measured in terms of wage (Forbes et al., 2010). Other studies evaluated productivity based on the effect of health and education variables on the aggregate output and on labour 
supply (Nwosu, 2015; Forbes et al., 2010). Yet other studies evaluated the effects of health and education on productivity by evaluating their impacts on total factor productivity. These studies have mainly used household income dynamic surveys, panel data approaches (Cole and Neumayer, 2006). Some of the results of these studies were conflicting, hence the need for more investigation. In reviewed literature, panel data analysis was the most common approach. Whilst panel data are good in addressing estimation issues, they do not provide a room for contextrelevant policy for a specific country. This implies that policy suggestions from these studies might be irrelevant to the South Africa context. Therefore, the contribution of the study to the literature is that it tests hypotheses about the effect of HEE, HE and health on productivity in the context of South Africa, by applying ARDL time series for country-specific policy suggestions. The methodology used is explained next.

\section{Methodology}

This section showcases methodological issues relating to the model specification, the justification for the study, data sources, analysis and interpretation of data analysis and finally the discussion of findings. Hence the subsection that follows begin with specification of model to be adopted in this model.

\subsection{Model specification}

The central objective of this paper is to view human capital from the perspective of higher education enrolment and higher education graduates and health. We therefore integrate health and higher education in an aggregate production function in a well-specified structure. The study controls for the presence of the true impacts of health and higher education on the South African productivity model via total factor productivity (TFP). The novelty and efficiency of the input combination is demonstrated through the adoption of the Cobb Douglas function.

Taking the augmented type of Cobb-Douglas production function from Bloom et al. (2001); De la Fuente (2011) and Bokana and Akinola (2017) the model is written as follows:

$$
Y_{t}=A_{t} K_{t}^{a k} H_{t}^{a h} L_{t}^{a l}
$$

where:

$Y_{t}=$ Total output in South Africa at time $t, L_{t}=$ Employment level measured in terms of the labour force (those who are working and those who are seeking work actively), $K_{t}=$ Physical stock measured at time $t, H_{t}^{a h}=$ Stock of human capital at time $\mathrm{t}$ such that $H_{t}=\left(H E E_{t} \& H E G_{t}, H I_{t}\right)$ with HEE, HEG $\mathrm{Hl}$ representing 
respectively higher education enrolments, higher education graduates and health. HEE is measured in terms of number enrolled in higher education, HEG measured in terms of number of graduated students, and $\mathrm{Hl}$ measured in terms of life expectancy. Bloom et al. (2001) introduced a health variable as a proxy for human capital in the production function. Bokana and Akinola (2017) introduced HEE and $H E G$ into productivity of human capital formulation. Elasticity with respect to the stock of the various factors is measured through the coefficient $\alpha_{i}$ to control for total factor productivity. The new Cobb Douglas function is in the form:

$$
Y_{t}=A_{t} K_{t}^{a k} H e_{t}^{a h e} H g_{t}^{a h g} H I_{t}^{a h l} L_{t}^{a l}
$$

The foregoing equation is constant return to scale $a k+a h e+a h g+a h l+a l=1$ and equation 3.2 can be linearized by taking logs of both sides and hence a growth rate path of $y=d \ln ({ } / L) d t$ could be assumed. This linearized shown in model (3.3) relates the annual percentage growth of output per labour to the growth of education capital per labour and physical capital per labour. The term $u_{i t}$ has been introduced to capture the random shock and the unexplained phenomenon which could not be captured in the process of adjustment. Model (3.3) is shown as:

$$
y_{t}=a_{t}+a k\left(k_{t}\right)+a h e(h e)_{t}+a h(h l)_{t}+a h g(h g)_{t}+a l(l)+u_{i t}
$$

Since $a_{t}$ accounts for the residual growth known as TFP.

$$
a_{t}=y_{t}-a k\left(k_{t}\right)-a h e(h e)_{t}-a h(h l)_{t}-a h g(h g)_{t}-a l(l)-u_{i t}
$$

This model introduced the lag of dependent variable to the right hand side in order to build a dynamic model into the system for TFP (equation 3.5). This is because previous output can influence current output.

$$
a_{t}=y_{t}+a_{t-1}-a k\left(k_{t}\right)-a h e(h e)_{t}-a h(h l)_{t}-a h g(h g)_{t}-a l(l)-u_{i t}
$$

To make our equation dynamic, equation (3.6) leads to ARDL model specification as follows:

$$
\begin{aligned}
& \Delta \ln a_{t}=\beta_{0}+\phi a_{t-1}+\sum_{i=1}^{p} \beta_{i} \Delta a_{t-1}+\delta_{1} \ln y_{t-1}+\sum_{w=0}^{q l} \rho_{w} \Delta \ln y_{t-w}+\delta_{2} \ln k_{t-1}+ \\
& +\sum_{j=0}^{q 2} a_{j} \Delta k_{t-j}+\delta_{3} \ln h e_{t-1}+\sum_{k=0}^{q 3} \vartheta_{k} \Delta h e_{t-k}+\delta_{4} \ln h l_{t-1}+\sum_{l=0}^{q 4} \gamma_{l} \Delta h l_{t-l}+ \\
& +\delta_{5} \ln h g_{t-1}+\sum_{v=0}^{q 5} \eta_{v} \Delta h g_{t-v}+\delta_{6} \ln l_{t-1}++\sum_{v=0}^{q 6} \Omega_{v} \Delta l_{t-v} u_{t}
\end{aligned}
$$

A priori expectations require that $h e, h l, h g, l, y>0$. We estimate Model (3.6). 


\subsection{Justification for the methodology adopted}

As is usually the case in analyses of this nature, unit roots tests will be first conducted. We further consider the co-integration analysis to determine the appropriateness of our methodology. The possible conditions are listed below:

(i) Under a condition where all variables are stationary at levels, for instance, integrated of order I(0), the Ordinary Least Square (OLS) model would be most appropriate. This is the condition for stationarity.

(ii) It is usually advisable to adopt the vector error correction model (VECM) if all variables are non-stationary $\mathrm{I}(0)$ but are all stationary at $\mathrm{I}(1)$, as this is a simpler model built by the Johanson Co-integration Approach.

(iii) However, where some variables in the data are stationary at levels I(0) while some are integrated at $\mathrm{I}(1)$ or some variables are fractionally integrated which leads to some degree of complexity, Auto Regressive Distributive Lag (ARDL) would be appropriate (Chudik and Pesaran, 2013).

\section{Empirical data and analysis}

This study adopts time series data for South Africa for the period 1981-2015 to estimate the study's models. The data for higher education enrolment and higher education graduates are available in Baro and Lee's 1950-2010 and 2015-2040 data sets. Five-year average data set from Baro and Lee were adopted as this is the only data on higher education graduates that consistently covers the years under investigation. The paper adopted a method of interpolation as specified in literature to control for the missing data (Tang et al., 2008). Real GDP, employment rates and capital stock data, were sourced and adopted from Penn World Table 9.0 data from 1981 to 2015 . The study adopted 2015 as the most recent year because some of the variables required were not available post 2015 .

Real Output Per Worker:

(1) The conventional dependent variable in the Cobb- Douglas production function is the real output per labour. This study used real GDP in US dollars at constant prices (2000) in its adoption of Penn World Table 9.0 data from 1980-2015.

(2) Capital enters the production process together with labour in order to produce units of inputs. Capital is the tangible aspect of the production process that enhances performance. The Cobb- Douglas production function integrates capital stock per labour as the independent variable. Capital stock data is readily available for South Africa in the Penn World Table alongside other countries in Africa. To calculate capital stock for the period 1980-2015, the data is sourced from the Penn World Table 9.0. 
(3) In the context of this paper, TFP is the dependent variable as it is of great relevance in accounting for growth in the economy, variations in crosscountry per capita income, and economic fluctuations. The new growth theory postulates that, productivity growth is impacted by human capital levels. Growth in productivity thus needs to be measured to trace technical changes in a given economy.

(4) Health, higher education graduates and higher education enrolment are the three independent variables that proxy for human capital. In the context of this paper, it is argued that higher education graduates and health play key roles in determining human capital. Since not every student in higher education eventually graduates, we seek to determine if these three human capital variables could independently contribute to TFP. The paper aligns the annual data for the other variables in the Penn World Table as it follows the extant literature to interpolate five-year averages. Life expectancy is used to proxy the health variable.

\subsection{Data Analysis: Time series ARDL unit root results}

The presence of unit roots in economic models has significant theoretical implications as this often results in spurious regression analysis. In order to evaluate the true nature of the data applicable to the study's variables, this paper follows in the footprints of previous researchers. Certain variables appear to exhibit certain features such as mean reversion and finite variance; hence, the need to check for the presence of unit roots. We tested for the unit roots (stationarity) of variables by adopting a robust version of the Augmented Dickey-Fuller Test (ADF), Philip Peron and Dickey Fuller at the individual intercept to ensure consistency and to validate and compare the results (Moon and Perron, 2002; Frimpong, 2012). 
The result confirmed that all the variables were non-stationary at I (0), except higher education enrolment and higher education graduates, but when converted, all were made stationary after first differencing. The result is given in table 1 below. All the $p$-values are shown at $1 \%, 5 \%$ and $10 \%$ level of significance.

Table 1: Result of unit root on the series: $k, a, l, h l, y, h e, h g$ from year 1980-2015

\begin{tabular}{|l|c|c|c|c|c|c|c|c|c|}
\hline \multicolumn{4}{|c|}{ Aug Dick Fuller } & \multicolumn{3}{c|}{ Phillip Peron } & \multicolumn{3}{c|}{ Dick Fuller } \\
\hline \multicolumn{1}{|c|}{ Variables } & Prob & T-Stat & Sig & Prob & T-Stat & Sig & Prob & T-Stat & Sig \\
\hline $\begin{array}{l}\text { K (in log of the } \\
\text { value of capital } \\
\text { stock) }\end{array}$ & 0.0649 & -1.9141 & $\mathrm{I}(1)$ & 0.0002 & 4.2410 & $\mathrm{I}(0)$ & 0.0661 & -1.9028 & $\mathrm{I}(1)$ \\
\hline $\begin{array}{l}\text { a( in log of output } \\
\text { residuals) }\end{array}$ & 0.0272 & -3.2277 & $\mathrm{I}(1)$ & 0.0242 & -3.277 & $\mathrm{I}(1)$ & 0.0025 & -3.2801 & $\mathrm{I}(1)$ \\
\hline $\begin{array}{l}\text { L (in log of labour } \\
\text { force value) }\end{array}$ & 0.0001 & -5.4243 & $\mathrm{I}(1)$ & -5.424 & 0.0001 & $\mathrm{I}(1)$ & 0.0298 & 2.2710 & $\mathrm{I}(0)$ \\
\hline $\begin{array}{l}\text { Hl (in log of life } \\
\text { expectancy) }\end{array}$ & 0.0057 & -3.9367 & $\mathrm{I}(0)$ & 0.0846 & 1.7834 & $\mathrm{I}(1)$ & 0.0016 & -3.6895 & $\mathrm{I}(0)$ \\
\hline $\begin{array}{l}\text { Y( in log of GDP } \\
\text { per capita) }\end{array}$ & 0.0024 & -4.8318 & $\mathrm{I}(1)$ & 0.0024 & -4.8334 & $\mathrm{I}(1)$ & 0.079 & -1.8160 & $\mathrm{I}(0)$ \\
\hline $\begin{array}{l}\text { he (number of } \\
\text { student enrolled in } \\
\text { higher education) }\end{array}$ & 0.0117 & -2.6832 & $\mathrm{I}(0)$ & 0.0133 & -2.6206 & $\mathrm{I}(0)$ & 0.0299 & -2.2764 & $\mathrm{I}(0)$ \\
\hline $\begin{array}{l}\text { hg (number of } \\
\text { students who } \\
\text { graduated from } \\
\text { higher education) }\end{array}$ & 0.0141 & -2.6055 & $\mathrm{I}(0)$ & 0.0041 & -3.0990 & $\mathrm{I}(0)$ & 0.0549 & -1.9950 & $\mathrm{I}(0)$ \\
\hline
\end{tabular}

Source: Authors' calculation, 2018. Legend: $\mathrm{K}$ is the stock of physical capital, a is the total factor productivity, $\mathrm{L}$ is the labor force in the economy and $\mathrm{Hl}$ is the life expectancy, $\mathrm{Y}$ is the output, He is higher education enrollment, hg is higher education graduates

Table 2 shows the lag length selection results of the series $k, a, l, h l, y, h e, h g$. “*” indicates lag order selected by the criterion and each test was carried out at $5 \%$ level of significance. Five alternative methods of lag length selection were compared, namely, the sequential modified LR test statistic (LR); final prediction error (FPE); Akaike information criterion (AIC); Schwarz information criterion (SC) and Hannan-Quinn information criterion (HQ). The result shows that lag length two is the most appropriate for our model. 
Table 2: Result of lag length selection on the series: k, a, l, hl, y, he, hg from year 1980-2015

\begin{tabular}{|c|c|r|r|r|r|r|}
\hline \multicolumn{7}{|c|}{ VAR Lag Order Selection Criteria } \\
\hline Endogenous variables: CTFP CK EMP LXP TOU TER \\
\hline 0 & LogL & LR & FPE & AIC & SC & HQ \\
\hline 1 & 1.7206 & NA & 5.2208 & 0.2593 & 0.5314 & 0.3509 \\
\hline 2 & 430.1111 & 517.4636 & 1.0915 & -17.4612 & -15.5566 & -16.8204 \\
\hline
\end{tabular}

Note: * indicates lag order selected by the criterion; LR: sequential modified LR test statistic (each test at 5\% level); FPE: Final prediction error; AIC: Akaike information criterion; SC: Schwarz information criterion; HQ: Hannan-Quinn information criterion.

Source: Authors' computation, 2018

Table 3 results supports the claim of a long run relationship among the variables under investigation. The normal rule of thumb is to reject the null hypothesis $H_{0}$ whenever the F- statistic is higher than the value in the upper bound and hence $6.620763>3.28$ as we adopt $5 \%$ level of significance. This affirms the presence of a long-run relationship among the variables of interest in the study. Hence, short run and long run regression analysis of the model is conducted through the adoption of the ARDL technique as shown below.

Table 3: Result of bound testing on the series: $k, a, l, h l, y, h e, h g$ from year 19802015

\begin{tabular}{|c|c|c|c|c|}
\hline \multicolumn{5}{|c|}{ F- Bound Test } \\
\hline Test Statistic & Value & Level of Significance & I(o) & I $(1)$ \\
\hline F-Statistics & 6.6208 & $10 \%$ & 1.9900 & 2.9400 \\
\hline K & 6 & $5 \%$ & 2.2700 & 3.2800 \\
\hline & & $2.5 \%$ & 2.5500 & 3.6100 \\
\hline & & $1 \%$ & 2.8800 & 3.9900 \\
\hline
\end{tabular}

Source: Authors' calculation, 2018 


\subsection{Normality test and CUSUM test of stability}

A normality and CUSUM Test show the stability and normality on the regression analysis conducted on the series $k, a, l, h l, y, h e, h g$. Hence, it indicates that all validation tests are conclusive.

Table 4: The result of heteroskedasticity test on the series: $k, a, l, h l, y, h e, h g$ from year $1980-2015$

\begin{tabular}{|l|r|l|r|}
\hline \multicolumn{4}{|c|}{ Heteroskedasticity Test: Breusch-Pagan-Godfrey } \\
\hline F-statistic & 1.0891 & Prob. F(19,13) & 0.4473 \\
\hline Observed R-squared & 20.2673 & Prob. Chi-Square(19) & 0.3787 \\
\hline Scaled explained SS & 2.3959 & Prob. Chi-Square(19) & 1.0000 \\
\hline
\end{tabular}

Source: Authors' calculation, 2018

Tests for heteroscedasticity and serial correlation were carried out on the regression analysis. It is expected that the variance of the error term will be constant for all levels of observation. If this assumption is violated, the heteroscedasticity problem sets in. We use the Breusch-Pagan-Godfrey test to confirm the existence of heteroscedasticity. The rule of thumb here is that three probability values must not be significant. As indicated in table 4, this condition was met, meaning that there is no heteroscedasticity in the model.

Table 5: Serial Correlation on the series: $k, a, l, h l, y, h e, h g$ from year 1980-2015

\begin{tabular}{|l|r|l|l|}
\hline \multicolumn{4}{|c|}{ Breusch-Godfrey Serial Correlation LM Test: } \\
\hline F-statistic & 1.9801 & Prob. F(2,17) & 0.1686 \\
\hline Observed R-squared & 6.2349 & Prob. Chi-Square(2) & 0.0443 \\
\hline
\end{tabular}

Source: Authors' Computation, 2018

Table 5 reports the result of the test conducted to ascertain the presence of serial correlation. Based on the rule of thumb, it is conventional for the values of both the F-statistic and Probability Chi-square not to be significant for the absence of serial correlation. Our result indicates at least a 50\% correlation freedom in our model.

Table 6: Error correction term on the series: $k, a, l, h l, y, h e, h g$ from year 19802015

\begin{tabular}{|c|c|c|c|c|}
\hline Variable & Coefficient & Std. Error & t-Statistic & Prob. \\
\hline CointEq(-1)* & -0.3064 & 0.0304 & -10.0823 & 0.0000 \\
\hline
\end{tabular}

Source: Authors' computation 2018 
Table 6 depicts the error correction term on $k, a, l, h l, y, h e, h g$. Having established that there is co-integration among the variables, the error correction model equation is adopted as further evidence as we undertake a one period lagged error correction term (ECT (-1)). ECT indicates the adjustment speed at which the variables revert to equilibrium with a corresponding negative sign indicating the right direction. Based on the rule of thumb, it is conventional for the ECT to be significant and negative. Hence, a negative coefficient (-0.306411) reflects that past disequilibrium takes a moderate speed of $30.6 \%$ to adjust to long run equilibrium, whereas significance at the $1 \%$ probability value $(0.0306)$ offers assurance that long run equilibrium could be achieved annually. A highly significant co-integrating term (ECT) confirms the existence of a stable long run relationship among the variables; hence, our variables have a stable long run association.

Table 7: The result of Johansen long-run co-integration regression (Trace Statistics)

\begin{tabular}{|c|c|c|c|c|}
\hline \multicolumn{5}{|c|}{ Unrestricted Co-integration Rank Test (Trace) } \\
\hline No. of $\mathrm{CE}(\mathrm{s})$ & Eigenvalue & Trace Statistic & Critical Value & Prob. $^{* *}$ \\
\hline None ${ }^{*}$ & 0.989808 & 241.6887 & 95.75366 & 0.0000 \\
\hline At most $1{ }^{*}$ & 0.592184 & 90.34698 & 69.81889 & 0.0005 \\
\hline At most $2^{*}$ & 0.530060 & 60.74799 & 47.85613 & 0.0020 \\
\hline At most $3^{*}$ & 0.480098 & 35.82802 & 29.79707 & 0.0089 \\
\hline At most 4 & 0.343598 & 14.24224 & 15.49471 & 0.0765 \\
\hline At most 5 & 0.010545 & 0.349831 & 3.841466 & 0.5542 \\
\hline
\end{tabular}

Note: Trace test indicates 4 co-integrating equation(s) at the 0.05 level and $*$ denotes rejection of the hypothesis at the 0.05 level.

Source: Authors' calculation, 2018

Table 8: The result of Johansen long-run co-integration regression (Maximum Eigenvalue)

\begin{tabular}{|l|r|r|r|r|}
\hline \multicolumn{5}{|c|}{ Unrestricted Co-integration Rank Test (Maximum Eigenvalue) } \\
\hline \multicolumn{1}{|c|}{ No. of CE(s) } & Eigenvalue & \multicolumn{1}{c|}{ Statistic } & Critical Value & \multicolumn{1}{c|}{ Prob.** } \\
\hline None ${ }^{*}$ & 0.989808 & 151.3417 & 40.07757 & 0.0001 \\
\hline At most 1 & 0.592184 & 29.59898 & 33.87687 & 0.1490 \\
\hline At most 2 & 0.530060 & 24.91997 & 27.58434 & 0.1057 \\
\hline At most 3 & 0.480098 & 21.58578 & 21.13162 & 0.0432 \\
\hline At most 4 & 0.343598 & 13.89241 & 14.26460 & 0.0572 \\
\hline At most 5 & 0.010545 & 0.349831 & 3.841466 & 0.5542 \\
\hline
\end{tabular}

Note: Max-eigenvalue test indicates 1 co-integrating equation(s) at the 0.05 level * and denotes rejection of the hypothesis at the 0.05 level

Source: Authors' calculation, 2018 
This section reports on the result of the Johansen long-run co-integration analysis. It examines whether the variables under investigation co-move or have long run association. The result from the Trace statistic and Max-Eigen statistic is reported alongside the probability value. The null hypothesis H0: indicates no co-integration among the variables. The result of the trace statistic indicates longrun co-integration at most four. This is because the critical values at 5\% level of significance are higher than the value at Trace statistic. The result hence confirms a long-run relationship among the variables. Again, from the Maximum Eigenvalue result, we reject the null hypothesis at 5\% level of significance at none and at most three. This result again validates the existence of a long-run relationship among the variables.

Table 9: Short run time series regression result dependent variable: CTFP

\begin{tabular}{|c|c|c|c|}
\hline \multicolumn{3}{|c|}{ Selected Model: ARDL $(2,1,1,2,0,2)$} & R-squared $=0.99$ \\
\hline Variable & Coefficient & Std. Error & Prob.* \\
\hline$a(-1)$ & 0.5776 & 0.1602 & 0.0019 \\
\hline$a(-2)$ & -0.4499 & 0.1531 & 0.0084 \\
\hline $\mathrm{k}$ & -0.0905 & 0.1383 & 0.5209 \\
\hline$k(-1)$ & -0.3621 & 0.1246 & 0.0090 \\
\hline $\mathrm{D}(y)$ & 0.2301 & 0.1285 & 0.0893 \\
\hline 1 & 0.0060 & 0.0099 & 0.5524 \\
\hline$l(-1)$ & 0.0194 & 0.0099 & 0.0648 \\
\hline $\mathrm{hl}$ & -0.3309 & 0.0959 & 0.0027 \\
\hline$h l(-1)$ & 0.6798 & 0.2006 & 0.0031 \\
\hline$h l(-2)$ & -0.3851 & 0.1127 & 0.0029 \\
\hline hg & 0.0281 & 0.1997 & 0.8894 \\
\hline he & 0.0041 & 0.0241 & 0.8654 \\
\hline he(-1) & 0.0424 & 0.0317 & 0.1957 \\
\hline $\mathrm{C}$ & 8.6617 & 1.73467 & 0.0001 \\
\hline
\end{tabular}

Source: Authors' calculation 2018

\subsection{Analysis of the findings}

Table 9 above presents the summary results of the short-run relationships between South African TFP and the series that determine it. Six variables, including capital stock, employment rates, GDP, life expectancy, higher education graduates and higher education enrolment are regressed in this model. The findings indicate consistent statistical significance of the dependent variable from the past lag to the present. Current capital stock, employment rates and, higher education do not 
jointly influence TFP in South Africa. Hence, in the short run, these variables are not performing well enough to impact on TFP. However, comparison with the lag which reflects the past period exhibits a reversed relationship as capital stock, employment rates, and health represented by life expectancy as well as higher education enrolment all exhibit statistical significance. In contrast, the past lag of capital stock and higher education enrolment are inversely related to TFP, meaning that if they increase in the short run, this would invariably lead to a short run decrease in TFP. A positive relationship exists for lag of employment rates and life expectancy. The implication is that an increase in these two variables will lead to TFP in South Africa in the short run.

Table 10: Long run regression result on the series: $k, a, l, h l, y, h e, h g$ from year 1980-2015

\begin{tabular}{|c|c|c|c|}
\hline \multicolumn{4}{|c|}{ ARDL Long Run Form } \\
\hline \multicolumn{4}{|c|}{ Dependent Variable: D(CTFP) } \\
\hline \multicolumn{4}{|c|}{ Selected Model: ARDL $(1,1,2,2,2,0)$} \\
\hline Variable & Coefficient & Std. Error & Prob. \\
\hline $\mathrm{C}$ & 7.9393 & 1.962781 & 0.0007 \\
\hline $\mathrm{a}(-1)^{*}$ & -0.3064 & 0.113035 & 0.0139 \\
\hline 1 & 0.0381 & 0.0134 & 0.0138 \\
\hline $1(-1)$ & 0.0218 & 0.0101 & 0.0435 \\
\hline $\mathrm{hl}(-1)$ & -0.0203 & 0.0065 & 0.0056 \\
\hline $\mathrm{k}(-1)$ & -0.3621 & 0.1245 & 0.0090 \\
\hline$y(-1)$ & -0.5282 & 0.1357 & 0.0010 \\
\hline $\mathrm{y}$ & 0.8211 & 0.2965 & 0.0160 \\
\hline $\mathrm{hg}^{* *}$ & 0.0114 & 0.1662 & 0.9457 \\
\hline $\mathrm{D}(\mathrm{hl})$ & -0.0813 & 0.0658 & 0.2320 \\
\hline $\mathrm{D}(\mathrm{hl}(-1)$ & 0.1012 & 0.0768 & 0.2037 \\
\hline $\mathrm{D}(\mathrm{y})$ & 0.2300 & 0.1284 & 0.0893 \\
\hline $\mathrm{D}(\mathrm{y}(-1))$ & 0.2982 & 0.1189 & 0.0214 \\
\hline $\mathrm{D}(\mathrm{he}(-1))$ & 0.0538 & 0.0158 & 0.0030 \\
\hline
\end{tabular}

Source: Authors' calculation, 2018

Table 10 displays the summary results on the long-run relationships between South African TFP and the series that determine it. Of greater importance is the long run result as it has policy implications. A total of six variables, including capital stock, employment rates, life expectancy, GDP, higher education graduates and higher education enrolment are regressed in this model. Employment rate, life expectancy, GDP growth, capital stock and higher education enrolment indicate no impact significantly on productivity in the long run in South Africa, while higher 
education graduates does. Many graduates in South Africa are not indigenous and after acquiring their degree, they return to their home country. Under-utilization of South African graduates could also account for this finding. However, the direction of contribution differs across variables. When lagged by one, life expectancy, GDP growth, and capital stock exhibit an inverse relationship with productivity. This shows that in the previous period, there was an inverse relationship among these variables and productivity. While employment rates, higher education enrolment and GDP growth have a positive impact on productivity, when differenced, the variables appear to have mixed impact. Finally, capital stock, and the lag of life expectancy exhibit an inverse relationship with productivity.

\section{Results and discussion}

As noted previously, South Africa has one of the highest rates of HIV and TB incidence in the world as well as a low higher education graduation rate. This can be explained by apartheid legacies and it negatively impacts human capital development. However, our findings on the long run relationship results indicate that employment rates, life expectancy, GDP growth, capital stock and higher education enrolment ultimately have a significant effect on productivity in South Africa. While GDP growth, employment rates and higher education enrolment have a positive impact on productivity, this result is not promising because chronic life threatening diseases have yet to be brought under control. This probably explains the finding on the inverse effect of life expectancy on productivity in the country.

Only a healthy worker will have more time to devote to productive activity, while an unhealthy one will be unable to work. In this respect, the study found that a $1 \%$ increase in the employment rate would cause a 3.8\% increase in the productivity level in South Africa. Apart from the fact that these results support a priori expectations, they strongly support Forbes et al (2010). Furthermore, while the negative relationship between health and higher education graduates variables supports Eggoh et al. (2015) findings, it negates those of Li and Huang (2009); and McDonald and Roberts (2002) who found a positive relationship between health and education in their models.

One of the findings from the present study was that capital stock, and the lag of life expectancy exhibited an inverse relationship with productivity. This could be because capital accumulation without corresponding human capital effects could yield a less than proportionate return. Furthermore, the lag of life expectancy would not support productivity as high levels of uncertainty about what the future holds in the wake high prevalence of disease, particularly HIV and TB, could weaken human capital, leading to inverse levels of productivity effects.

While higher education enrolment when differenced, strongly supported productivity growth, and a $1 \%$ in increase would cause productivity to increase by $5.3 \%$, the 
reverse is the case with higher education graduates. The latter result is contrary to human capital theory as output from higher education is expected to improve labour as an input, leading to productivity growth. However, it seems that our postulated hypotheses are supported by the evidence. In fact, many graduates in South Africa do not remain within the system. This could be a result of the fact that those who drop out do so because they came from poorly equipped schools and were enrolled in university programs that are relevant to the skills need of the economy. When they drop out, they go with some part of these skills which employer capitalize on by providing additional training. This drop out and training of partly skilled enrolments (including in most part these dropouts) has a positive effect on productivity. This explanation support also the finding that higher education graduates relate negatively to productivity. In fact, as graduates of higher education come largely from skills not required by the economy, they are most unlikely to be employed. The positive effect of higher education enrolment on productivity occurring side- by-side with the negative effect of higher education graduates on productivity, suggest that policy makers should not pride in increased enrolments. They should ensure that the school sector is strengthened to ensure increased enrolment results in graduations in skills needed by the economy. Furthermore, whilst heath-strengthening programme on the part of the government are worthwhile in increasing survival, they do not contribute to productivity unless they are accompanied by school sector outcomes in key skills. The prevailing context in South Africa suggest also spill over effects on capital stock, which relate negatively to productivity. This could be because capital accumulation without corresponding human capital effects could yield less than proportionate returns on capital productivity. To deal with these productivity issues, the government should adopt act jointly on school and health sector jointly to improve the overall productivity.

\section{Conclusion}

At the beginning of the paper, the health and education context of the country prompted the formulation of the hypothesis that widespread antiretroviral without corresponding school sector's focus on economy's relevant skills were to lead to reduced productivity effects of health. It was also hypothesized that given the contexts, enrolments will have a positive effect on productivity because enrolments include those who drop out from university programmes that are relevant to the economy. Finally, we hypothesizes that higher education graduates will relate negatively to output because those who graduate have largely skills that mismatch the economy's skills requirement. Most of the studies conducted in this area have largely used panel data analysis and no study investigated the effect of higher education graduates, higher education enrolment and health in the country with the aim to tests South Africa context-specific hypotheses. This study contributed to the literature in that it tested hypotheses about the effect of HEE, HE and Health 
on productivity in the context of South Africa, by applying ARDL time series for country-specific policy suggestions. The evidence produced supported all our hypotheses. The policy implications is that increase in enrolments alone should not be a policy focus for the country but a joint effort in strengthening the school sector and the socioeconomic sector should be pursued as it would results in more productivity and spill overs in the economy. The limitation of our investigation lies in the fact that the study did not have access to HIV/AIDS and TB data but used a life expectancy data, which capture mortality aspect of the burden of diseases and not morbidity aspects. Incorporating HIV /AIDs and TB data in future analyse is recommended.

\section{References}

AVERT (2017) "HIV AND AIDS IN SOUTH AFRICA", https://www.avert.org/ professionals/hiv-around-world/sub-saharan-africa/south-africa.

Becker, G. S. (1962) "Investment in human capital: A theoretical analysis", The journal of political economy, Vol, 70, No. 5, pp. 9-49, doi: 10.1086/258724.

Bloom, D.E., Canning D. (2002) "The Health and Wealth of Nations", Science's Compass, Vol, 287, pp. 1207-1209, doi: 10.3386/w8714.

Bloom, D.E. et al. (2001) "The Effect of Health on Economic Growth: Theory and Evidence”, Working Paper 8587, http://www.nber.org/papers/w8587.

Bokana, K.G., Akinola, G.W. (2017) "Productivity Effects of Higher Education Capital in Selected Countries of Sub-Saharan Africa", Zbornik radova Ekonomskog fakulteta u Rijeci: časopis za ekonomsku teoriju i praksul Proceedings of Rijeka Faculty of Economics: Journal of Economics and Business, Vol. 35, No. 1, pp. 173-198, doi: 10.18045/zbefri.2017.1.173.

Branson, N., Leibbrandt M. (2013) "Educational Attainment and Labour Market Outcomes in South Africa, 1994-2010", OECD Economics Department Working Papers, No. 1022, OECD Publishing, Paris, doi: 10.1787/5k4c0vvbvv0q-en.

Chigwedere, P., et al. (2008) "Estimating the Lost Benefits of Antiretroviral Drug Use in South Africa", JAIDS Journal of Acquired Immune Deficiency Syndromes, Vol. 49, No. 4, pp. 410-415, doi: 10.1097/QAI.0b013e31818a6cd5.

Chudik, A., Pesaran, M. (2013) "Large Panel Data Models with Cross-Sectional Dependence: a Survey", CAFE Research Paper. No. 13. pp. 15, doi: 10.2139/ ssrn.2316333.

Colantonio, E., N. et al. (2010) "On Human Capital and Economic Development: Some Results for Africa”, Procedia Social and Behavioral Sciences, Vol. 9, pp. 266-272, doi: 10.1016/j.sbspro.2010.12.148.

Cole, M. A., Neumayer, E. (2006) "The impact of poor health on factor productivity: an empirical investigation", Journal of development studies, Vol. 42, No. 6, pp. 918-938, doi: 10.1080/00220380600774681. 
De La Fuente, A. (2011) "Human capital and productivity", Nordic Economic Policy Review, Vol. 2, No. 2, pp. 103-132, http://pareto.uab.es/wp/2011/86011. pdf.

Eggoh J. et al. (2015) "Education, Health and Economic Growth in African Countries", Journal of Economic Development, Vol. 40, No. 1, p. 93, www.jed. or.kr/full-text/40-1/4.pdf.

Fleisch, B. (2008) "Primary education in crisis: Why South African schoolchildren underachieve in reading and mathematics", Cape Town: Juta \& Co. www.scirp. org/(S(i43dyn45teexjx455qlt3d2q))/reference/References.

Forbes, M. et al. (2010) "The Effects of Education and Health on Wages and Productivity", Productivity Commission Staff Working Paper. Australian Government Productivity Commision. https://www.pc.gov.au/research/ supporting/.../education-health-effects-wages.pdf.

Frimpong, P.B., Adu G. (2012) "Population Health and Economic Growth: Panel Cointegration Analysis in Sub-Saharan Africa", Journal of African Business, Vol. 15, No. 1, pp. 36-48, doi: https://doi.org/10.1080/15228916.2014.881227.

Grossman, M. (1972) "On the Concept of Health Capital and the Demand for Health", Journal of Political Economy, Vol. 80, No. 2, pp. 223-255, doi: $10.1086 / 259880$.

Gyimah-Brempong, K., Wilson M. (2004) "Health and Economic Growth in SubSaharan African and OECD Countries", Quarterly Review of Economics and Finance, Vol. 44, pp. 296-320, doi: 10.1016/j.qref.2003.07.002.

Higher Education South Africa, HESA (2018) "Higher education challenges: presented by Higher Education South Africa (HESA)", https://pmg.org.za/ committee-meeting/17037/.

Katz I.T., et al. (2013) "PEPFAR in transition - implications for HIV care in South Africa”. New England Journal Medicine, Vol. 369, pp. 1385-138, doi: 10.1056/ nejmp1310982.

Kevany S., et al. (2013) "Improving resource allocation decisions for health and HIV programmes in South Africa: bioethical, cost-effectiveness and health diplomacy considerations", Glob Public Health, Vol. 8, pp. 570-587, doi: 10.1080/17441692.2013.790461.

Li, H., Huang L. (2009) "Health, Education and Economic Growth in China: Empirical Findings and Implication", China Economic Review, Vol. 20, No. 3, pp. 374-387, doi: 10.1016/j.chieco.2008.05.001.

Li, H., Huang L. (2010) "Health, Education, and Economic Growth in East Asia", Journal of Chinese Economic and Foreign Trade Studies, Vol. 3, No. 2, pp. 110-131, doi: 10.1108/17544401011052267.

Lindahl, M., Krueger, A.B. (2001) "Education for Growth: Why and for Whom?" Journal of Economic Literature, Vol. 39, No. 4, pp. 1101-1136, doi: 10.1257/ jel.39.4.1101. 
Lucas, R. (1988) "On the Mechanics of Economic Development", Journal of Monetary Economics 22, pp. 3-42, doi: 10.1016/0304-3932(88)90168-7.

Mankiw, N.G., et al. (1992) "A contribution to the empirics of economic growth", The quarterly journal of economics, Vol. 107, No. 2, pp. 407-437, doi: $10.2307 / 2118477$.

Mayosi B.M., Benatar S.R. (2014) "Health and Health Care in South Africa - 20 Years after Mandela", New England Journal of Medicine, Vol. 371, pp. 13441353, doi: 10.1056/NEJMsr1405012.

McDonald, S., Roberts J. (2002) "Growth and Multiple Forms of Human Capital in an Augmented Solow Model: A Panel Data Investigation", Economics Letters, Vol. 74, pp. 271-276, doi: 10.1016/s0165-1765(01)00539-0 01.

Moon, H.R., Perron, B. (2002) "Testing for a Unit Root in Panels with Dynamic Factors", USC CLEO Research Paper No. C01-26., Vol. 122, No. 1, pp. 81126. Available at SSRN: https://ssrn.com/abstract=296229, or doi: $10.2139 /$ ssrn.296229.

Nelson, R. R., Phelps, E. S. (1966) "Investment in Humans, Technological Diffusion, and Economic Growth", The American economic review, Vol. 56, No. 1/2, pp. 69-75, doi: http://www.jstor.org/stable/1821269.

Nwosu C.O.(2015) "An Analysis of the Relationship Between Health and the Labour Market in South Africa" School of Economics, Faculty of Commerce University of Cape Town. https://open.uct.ac.za/bitstream/handle/11427/15695/ thesis_2015_nwosu_chijioke_osinachi.pdf?sequence.

OECD (2018) "Enhancing labour market relevance and outcomes through higher education", OECD Library, doi: 10.1787/9789264301757-en.

Omarjee, L (2018) "NHI rollout could be delayed" - Motsoaledi. https://www.fin24. com/Companies/Health/nhi-rollout-could-be-delayed-motsoaledi-20181101.

Ram, R. (2007) "IQ and Economic Growth: Further Augmentation of Mankiw Romer-Weil Model”, Economics Letters, Vol. 94, pp. 7-11, doi: 10.1016/j. econlet.2006.05.005.

Rensburg, D. et al. (2005) "Tuberculosis control in South Africa: reasons for persistent failure", Acta Academica Supplementum, No.1, pp. 1-55. journals. ufs.ac.za/index.php/aa/article/download/1042/1031.

Stander M.P., et al. (2016) "Depression and the Impact on Productivity in the Workplace: Findings from a South African Survey on Depression in the Workplace", J Depress Anxiety S2:012. doi: 10.4172/2167-1044.S2-012.

Statistics South Africa (2017) "Statistics South Africa Mid-year population estimates 2017", www.statssa.gov.za.

Suhrcke, M., et al. (2005) "The contribution of health to the economy in the European Union Office for Official Publications of the European Communities", Vol. 120, No. 11, pp. 994-1001, doi: 10.1016/j.puhe.2006.08.011. 
Tang, Q., et al. (2008) "Compensation of requantization and interpolation errors in MPEG-2 to H. 264 transcoding", IEEE Transactions on Circuits and Systems for Video Technology, Vol. 18, No. 3, pp. 314-325, doi: 10.1109/tcsvt.2008.918443.

Van der Berg, S. (2008) "How effective are poor schools? Poverty and educational outcomes in South Africa", Studies in Educational Evaluation, Vol. 34, pp.145154, doi: 10.1016/j.stueduc.2008.07.005.

Wabiri N., Tafta N. (2013) "Socio-economic inequality and HIV in South Africa", BMC Public Health Vol. 13; 2013PMC422841, doi: 10.1186/1471-2458-131037.

Worldlink Africa. (2013) Vol. 23, No.2, www.wfpma.com/sites/default/files/ publications/WorldLink.

Zuma, K., et al. (2014) "HIV epidemic in South Africa: A comparison of HIV epidemic patterns of two extreme provinces in South Africa", Vol. 19, No. 1, doi: 10.4102/hsag.v19i1.716. 


\title{
Utjecaj ljudskih resursa na produktivnost: empirijsko istraživanje zdravlja i visokog obrazovanja u Južnoj Africi
}

\author{
Josue Mbonigaba ${ }^{1}$, Akinola Gbenga Wilfred ${ }^{2}$
}

\begin{abstract}
Sažetak
Enormna opterećenost bolestima, lošim ishodima učenja u visokom obrazovanju u Južnoj Africi i njihova interakcija u smislu utjecaja na produktivnost ljudskih resursa iziskuju istraživanja za konkretne smjernice u okviru politike. $U$ tom smislu, svrha ovog rada je istražiti ovaj odnos, zajedno s drugim čimbenicima, promatrajući ljudske resurse iz perspektive zdravlja, upisa u visoko obrazovanje (HEE) $i$ diplomiranih studenata visokog obrazovanja (HEG). U istraživanju se primjenjuje model vremenskih serija s autoregresijskim distribuiranim pomacima (ARDL) s podacima koji obuhvaćaju razdoblje od 1980. do 2015. godine. Studija je pokazala da, dok BDP raste, stope zaposlenosti i HEE imaju pozitivan učinak na produktivnost u Južnoj Africi; kapital $i$ životni vijek su inverzni u odnosu na produktivnost. Naime, rezultati ovog istraživanja potvrđuju hipotezu da bez odgovarajućeg školskog sektora usmjerenog na potrebne vještine, široko rasprostranjena antiretroviralna terapija u prevenciji HIV-a stanovništva, a s tim $i$ njihovo preživljavanje, negativno utječe na produktivnost. Nadalje, rezultati potvrđuju da uključivanje u obrazovanje djeluje pozitivno na produktivnost, jer obuhvaća pojedince koji su djelomično vješti u programima potrebnim gospodarstvu. Naposljetku, potvrđena je i hipoteza da su ishodi učenja diplomskih studija negativni u odnosu na produktivnost zbog neusklađenosti vještina diplomanata i potreba gospodarstva. Stoga se predlaže da se u okviru politike za povećanje produktivnosti u Južnoj Africi, poduzmu zajednički napori u školskom $i$ zdravstvenom sektoru.
\end{abstract}

Ključne riječi: produktivnost, ljudski resursi, upis u visoko obrazovanje, diplomanti visokog obrazovanja, ARDL, Južna Afrika

JEL klasifikacija: I1, I15, I21, I23, J24, O4

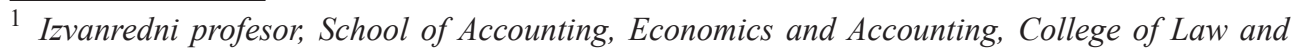
Management, University of Kwazulu Natal, Južna Afrika. Znanstveni interes: zdravstvena ekonomija.E-mail: Mbonigaba@ukzn.ac.za.Tel.:+27768706031 (osoba za kontakt).

2 Doktor ekonomskih znanosti, School of Accounting, Economics and Finance, College of Law and Management Studies, University of KwaZulu-Natal, Westville, Durban, 4000, Južna Afrika. Znanstveni interes: razvoj ljudskih resursa. Tel.: +27739210781. E-mail: gbenga. akinola@fuoye.edu.ng. 


\section{Appendix}

Figure A1: The relationships between productivity and all other variables adopted in this paper

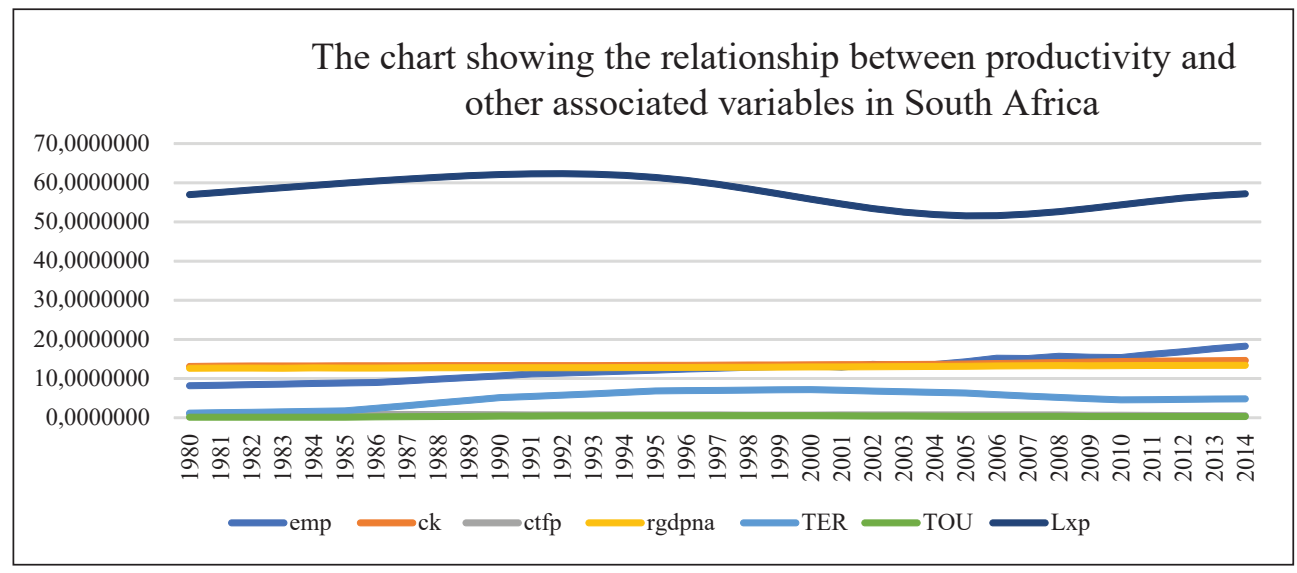


Figure 1: Normality Test

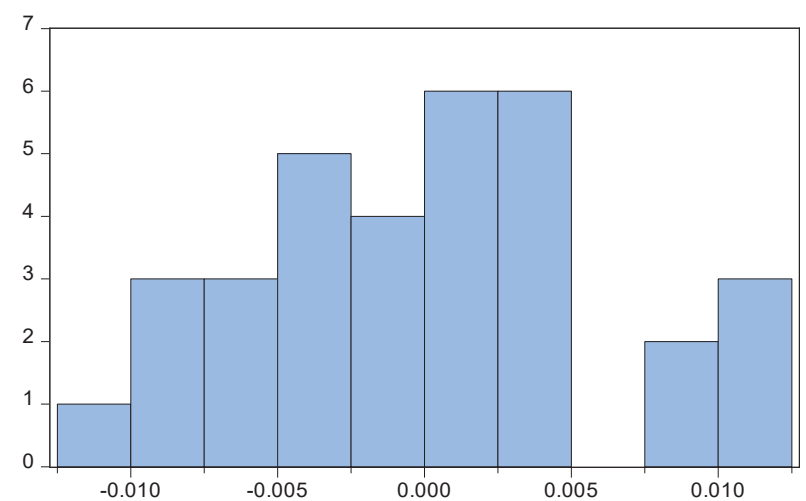

Series: Residuals

Sample 335

Observations 33

Mean

$-1.33 e-17$

Median $\quad 0.000313$

Maximum $\quad 0.012276$

Minimum $\quad-0.011706$

Std. Dev. $\quad 0.006121$

Skewness $\quad 0.255275$

Kurtosis $\quad 2.523508$

Jarque-Bera $\quad 0.670594$

Probability $\quad 0.715125$

Source: Authors' calculation, 2018

Figure 2: Lag Strength Measurement

Akaike Information Criteria (top 20 models)

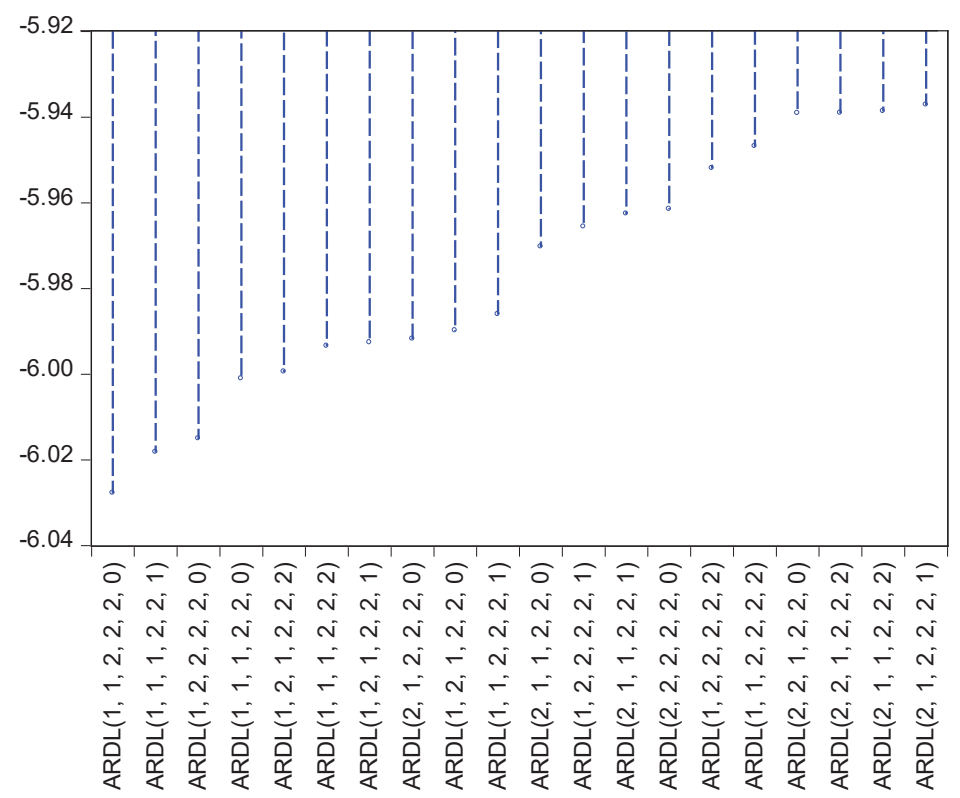

Source: Authors' calculation, 2018 
